\title{
Role of organic soil amendment of paramagnetic humus and compost for rehabilitation of post tin-mined tropical land
}

\author{
Cahyono Agus ${ }^{\mathrm{a}}$, Abel Hendryan ${ }^{\mathrm{a}}$, Victory Harianja ${ }^{\mathrm{a}}$, Eny Faridah ${ }^{\mathrm{a}}$, Winastuti D \\ Atmanto $^{\mathrm{a}}$, Pita A. B. Cahyanti ${ }^{\mathrm{b}}$, Dewi Wulandari ${ }^{\mathrm{c}, \mathrm{d}}$, Ambar Pertiwiningrum, \\ Bambang Suhartanto ${ }^{\mathrm{e}}$, Idi Bantara ${ }^{\mathrm{f}}$, Benny P Hutahaean ${ }^{\mathrm{g}}$, Bintoro Suparto ${ }^{\mathrm{h}}$, Tri \\ Lestari $^{\mathrm{i}}$
}

\author{
${ }^{a}$ Faculty of Forestry, Universitas Gadjah Mada, Jl. Agro - Bulaksumur Yogyakarta 55281, Indonesia. \\ ${ }^{b}$ Faculty of Engineering, Universitas gadjah Mad, Jl TeknikaYogyakarta 55281, Indonesia \\ ${ }^{c}$ Environmental Engineering, Universitas Islam Indonesia, Jl Kaliurang KM-13 Yogyakarta, Indonesia. \\ ${ }^{d}$ SEAMEO BIOTROP Jl Raya Tajur KM 6 Bogor Yogyakarta Indonesia \\ ${ }^{e}$ Faculty of Animal Sciences, Universitas Gadjah Mada, Jl Agro- Bulaksumur Yogyakarta 55281 Indonesia \\ ${ }^{f}$ BPDASHL Baturusa Cerucuk, Bangka Belitung Islands Province, Indonesia \\ ${ }^{g}$ PT Timah Tbk, Bangka Indonesia \\ ${ }^{h}$ District Government of Bangka, Indonesia \\ ${ }^{i}$ Universitas Bangka Belitung, Bangka, Indonesia
}

\begin{abstract}
Open tin mining on tropical Bangka Island, Indonesia exposed heavy metals that had become a major cause of land degradation and severe local_global environmental damage. The goal of this study is to accelerate the remediation of degraded ecosystems in tin mined land, and thereby promote sustainable land use and environmental productivity. To the tailings of a former tin mined on Bangka Island, we applied an organic amendment comprising compost and paramagnetic humus at dosages of $0 \%, 5 \%$, and $10 \%$, and analyzed the results using a factorial completely randomized design (FCRD). We found the soil from the former tin mining site to be acidic ( $\mathrm{pH}$ 5.34) and dominated by sand particles $(88 \%)$ with a very low cation exchange capacity. The soils also had a very low nutrient content (available and total-N, P, K, Ca, Mg), high toxicity levels of $\mathrm{Zn}, \mathrm{Cu}, \mathrm{B}, \mathrm{Cd}$ and $\mathrm{Ti}$, as well low toxicity levels of B, $\mathrm{Zn}, \mathrm{Cu}, \mathrm{Ti}, \mathrm{Cd}$. Organic soil amendments of organic paramagnetic materials and compost can improve soil quality by increasing the $\mathrm{pH}$, the high availability of $\mathrm{P}$ and $\mathrm{K}$ and the cation exchange capacity, as well as maintain low toxicity. The growth (high, diameter, biomass, top-root ratio) of the exotic pioneer plant Reutealis trisperma increases the quality of soils to which proper soil amendments have been applied. The overall concept and appropriate technology for rehabilitating the ecosystem of degraded tin-mined land in tropical regions which serve as the world's lungs, will strongly contribute to the development of a healthy and sustainable environment for all life on this planet.
\end{abstract}

Keywords: global environment, land degradation, land productivity, remediation, tropical tin mining

\section{Introduction}

The severe exploitation of tropical forest ecosystems, including open mining, has led to widespread degradation and damage $[1,2,3,4,5,6,7,8,9]$. Deforestation in mining concession areas in Indonesia in the 2009-2013 period totaled 488,374 hectares, which represents more than $10 \%$ of the deforestation in Indonesia [10]. There is an urgent need for remediation efforts at degraded land sites to stimulate the growth of vegetation. The high net primary production (NPP) of tropical ecosystems is influenced more by the nutrient cycling rate than by amount of nutrients available in soils $[1,2,3,5,6]$. The use of soil ameliorants and organic matter can address the physical, chemical, mineral, and biological properties of soil to optimize environmental sustainability and productivity $[7,9]$.

\footnotetext{
* Manuscript received March 1, 2018; revised July 8, 2019.

Cahyono Agus. Tel.: +62 8156888041; E-mail address: cahyonoagus@gadjahmada.edu.

doi: $10.12720 /$ sgce. $8.5 .556-561$
} 
Slow-release organic paramagnetic fertilizer (SROP), which was developed using the novel concept of synthetic humification, combines terra preta (black earth) soil and Hayes humus to obtain stable humus [11]. Biochar material is rich in carbon elements, stable, and enables the production of synthetic humus containing abundant carbon that is highly stable against both chemical and biological degradation when applied to agricultural land [11].

The rehabilitation of extremely degraded areas by re-vegetation of the fast -growing pioneer species Kemiri sunan (Reutealis trisperma) is expected to rapidly restore their dynamic organic- carbon stocks [6,7]. This species can adapt to degraded land with low $\mathrm{pH}$ and tolerates various types of soil. The introduction of soil -ameliorating materials such as compost and paramagnetic humus in tin -mined soil to boost the growth of the R. trisperma is expected to yield useful information regarding the effective rehabilitation of post -tin -mined land.

\section{Materials and Methods}

In this study, we collected tailing soil obtained from a former tin -mining area in Bangka Island from November 2016 to March 2017, conducted our study at the Laboratory of Intensive Silviculture, Faculty of Forestry, UGM Yogyakarta, and performed the soil and tissues analyseis at various laboratories at UGM Yogyakarta. We used a factorial completely randomized design with samples treated as follows: $\mathrm{CC}=$ control, $\mathrm{C} 5=$ tin tailing with $5 \%$ compost, $\mathrm{C} 10=$ tin tailing with $10 \%$ compost, $\mathrm{S} 5=$ tin tailing with $5 \%$ SROP and S10 = tin tailing with $10 \%$ SROP. In analyzing the data, we used an ANOVA completely randomized design to determine the impact of the treatments.

To identify the best treatment, we used Duncan's median value test at confidence intervals of $95 \%$ and 99\% to determine the median value that had the most significant impact. After cultivation, we recorded the height and diameter of the plant at two-week intervals for 12 weeks. Our soil analysis included soil texture, $\mathrm{pH} \mathrm{H} 2 \mathrm{O}, \mathrm{EC}$ and $\mathrm{EH}$ measured electrometrically, av-N using Devarda's alloy method, av-P using the Bray II method, av-K using the ammonium acetate method, and the cation exchange capacity (CEC) using the ammonium acetate method. We observed all the nutrients and other elements using scanning electron microscopy (SEM) + energy-dispersive X-ray spectroscopy (EDX). After harvesting the plant at 12 weeks, we determined the dry weight of its biomass using the SEM+EDX method. We analyzed all the data using SPSS 16 software.

\section{Result and Discussions}

We classified the tin -tailing soil as having a sandy loam texture dominated by a sand fraction (70$90 \%$ ), with the remaining fraction comprising dust and clay elements. The $\mathrm{pH}$ of the tin tailing soil was 5.34, which acidic. Its CEC was very low $(3.61 \mathrm{me} / 100 \mathrm{~g})$, and the availability of $\mathrm{P}$ and $\mathrm{K}$ in the soil was also very low $(0.38 \mathrm{ppm}$ and $0.07 \mathrm{me} / 100 \mathrm{~g}$, respectively), as were the total contents of $\mathrm{Ca}, \mathrm{Mg}$, and Mo (Table 1). The content of $\mathrm{B}$ and the metal elements $\mathrm{Zn}, \mathrm{Cu}, \mathrm{Ti}$, and $\mathrm{Cd}$ were excessively high, such that they were toxic. This is because tin -mining activities had resulted in the loss of the top soil layer and subsequent soil leaching. The high $\mathrm{pH}$ of the tin -tailing soil might result from acid primary materials with low alkaline cations $(\mathrm{Ca}, \mathrm{Mg}, \mathrm{K}$, and $\mathrm{Na}$ ) or from the elements leached from the soil [12]. The primary materials at the tin mining area in Selangor, Malaysia were identified as alluvial, with $\mathrm{pH}$ values in the range of 3.5-5.5, which are not significantly different from those found at the tin -mining area on Bangka Island [13]. The very low CEC in the tin -mining soil might result from the low clay mineral content, low organic material content, and low $\mathrm{pH}$. In addition to the loss of the top soil layer, this caused the tin-tailing soil to lack the macro nutrients $\mathrm{P}, \mathrm{K}, \mathrm{Ca}, \mathrm{Mg}$, and $\mathrm{Mo}$ and to have a surplus of the toxic elements $\mathrm{B}, \mathrm{Zn}, \mathrm{Cu}, \mathrm{Ti}$, and $\mathrm{Cd}$.

The application of soil-improving organic matter in compost and SROP to tin-tailing media can increase the $\mathrm{pH}$ from 5.34 (acid) to nearly neutral (5.96--7.33). Increasing the doses, especially the SROP fertilizer, causes the increase in $\mathrm{pH}$. We recorded $\mathrm{pH}$ values of 7.10 and 7.42 following the application of dolomite containing $\mathrm{Ca}$ and $\mathrm{Mg}$ during the preparation process. The application of the soil 
-improving organic matter increased the CEC from $3.61 \mathrm{me} / 100 \mathrm{~g}$ to $4.01--5.62 \mathrm{me} / 100 \mathrm{~g}$. Although a dose of $10 \%$ has not yet produced an optimal $\mathrm{CEC}$ value at a neutral $\mathrm{pH}$, the CEC value of the organic matter varied from 100 to $400 \mathrm{me} / 100 \mathrm{~g}$ [14].

We measured $23.18 \mathrm{ppm}$ of dissolved $\mathrm{N}$ in the tin -tailing soil, -which is considered to be a moderate content; however, it was not completely available to plants because some of it was in nitric form. The decrease in $\mathrm{N}$ was due to the fact that the $\mathrm{N}$ is easily lost or made unavailable to plants, via a $\mathrm{NO}_{3}$ leaching process, the denitrification of $\mathrm{NO}_{3}{ }^{-}$into $\mathrm{N}_{2}$, or the volatilization of $\mathrm{NH}_{4}{ }^{+}$into $\mathrm{NH}_{3}$, which is then fixated by clay minerals or consumed by soil microorganisms [14]. The small number of soil colloids in clay and organic matters might be the main causal factor of the loss of available $\mathrm{N}$ in the tin-tailing soil.

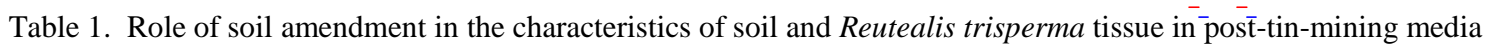

\begin{tabular}{|c|c|c|c|c|c|c|c|c|c|c|c|c|c|}
\hline \multirow[t]{2}{*}{ Parameter } & \multirow[t]{2}{*}{ unit } & \multirow[t]{2}{*}{ Compost } & \multirow[t]{2}{*}{ SROP } & \multicolumn{5}{|c|}{ Soil properties } & \multicolumn{5}{|c|}{ Tissue properties } \\
\hline & & & & Contr & $\mathrm{C}-5$ & $\mathrm{C}-10$ & $\mathrm{~S}-5$ & S-10 & Contr & $\mathrm{C}-5$ & C-10 & S-5 & S-10 \\
\hline $\mathrm{Ph}$ & & 7.42 & 7.1 & 5.34 & 5.98 & 6.85 & 6.83 & 7.33 & & & & & \\
\hline CEC & $\mathrm{me} / 100 \mathrm{~g}$ & & & 3.61 & 5.61 & 5.22 & 4.01 & 5.62 & & & & & \\
\hline EC & $\mathrm{mS}$ & 3.325 & 19.75 & 28.1 & 333 & 714 & 859.5 & 1320 & & & & & \\
\hline Eh & $\mathrm{mV}$ & -27 & 7 & 141 & 40.5 & -5 & -11 & -22.5 & & & & & \\
\hline $\mathrm{Av}-\mathrm{N}$ & ppm & & & 23.18 & 11.26 & 19.73 & 45.1 & 21.24 & & & & & \\
\hline Av-P & ppm & & & 0.38 & 0.85 & 1.52 & 26.27 & 80.09 & & & & & \\
\hline Av-K & $\mathrm{me} / 100 \mathrm{~g}$ & & & 0.07 & 0.24 & 0.57 & 1.62 & 2.49 & & & & & \\
\hline $\mathrm{C}$ & $\%$ & 34.88 & 39.99 & 10.4 & & & & & 56.67 & 53.46 & 55.69 & 55.43 & 53.72 \\
\hline $\mathrm{O}$ & $\%$ & 28.15 & 16.31 & 40.95 & & & & & 7.06 & 9.40 & 10.89 & 8.97 & 13.65 \\
\hline Tot-N & $\%$ & 9.49 & 19.29 & 6.28 & 7.41 & 7.07 & 7.1 & 6.28 & 26.12 & 23.78 & 22.19 & 23.1 & 20.16 \\
\hline Tot-P & $\%$ & 0.2 & 2.84 & 0 & 0.02 & 0.01 & 0.09 & 0.15 & 0.15 & 0.19 & 0.12 & 0.22 & 0.26 \\
\hline Tot-K & $\%$ & 0.56 & 2.76 & 0.19 & 0.25 & 0.19 & 0.29 & 0.26 & 0.90 & 1.12 & 0.83 & 1.17 & 0.87 \\
\hline Tot-Ca & $\%$ & 3.53 & 5.64 & 0 & 0.01 & 0.15 & 0.21 & 0.26 & 0.63 & 0.96 & 0.7 & 0.61 & 0.61 \\
\hline Tot-Mg & $\%$ & 0.66 & 1.13 & 0 & 0 & 0 & 0.1 & 0.07 & 0.42 & 0.55 & 0.33 & 0.59 & 0.5 \\
\hline Tot-S & $\%$ & 0.08 & 1.04 & 0.16 & 0.11 & 0.06 & 0.07 & 0.1 & 0.14 & 0.16 & 0.14 & 0.16 & 0.15 \\
\hline Tot-Si & $\%$ & 7.07 & 5.46 & 20.54 & 23.52 & 18.85 & 20.61 & 23.21 & 0.96 & 2.03 & 1.07 & 2.77 & 1.2 \\
\hline Tot-Al & $\%$ & 2.39 & 0.37 & 5.71 & 7.34 & 5.96 & 7.21 & 5.46 & 0.69 & 1.74 & 0.61 & 0.69 & 0.98 \\
\hline Tot-Fe & $\%$ & 3.03 & 0.29 & 0.67 & 0.71 & 0.48 & 0.49 & 0.05 & 0.12 & 0.22 & 0.22 & 0.15 & 0.23 \\
\hline Tot-B & $\%$ & 6.22 & & 4.35 & 0.78 & 4.75 & 2.18 & 4.15 & 1.52 & 1.37 & 3.3 & 1.28 & 4.23 \\
\hline Tot-Mo & $\%$ & 0.17 & 0.26 & 0 & 0.18 & 0.03 & 0 & 0.12 & 0.03 & 0.19 & 0 & 0.17 & 0 \\
\hline Tot-Mn & $\%$ & 0.15 & 0.16 & 0.06 & 0.01 & 0.06 & 0 & 0 & 0.01 & 0.06 & 0.07 & 0.06 & 0 \\
\hline Tot-Zn & $\%$ & 0.18 & 0.42 & 0.39 & 0.33 & 0.22 & 0.17 & 0.05 & 0.38 & 0.4 & 0.33 & 0.41 & 0.29 \\
\hline Tot-Cu & $\%$ & 0.16 & 0.7 & 0.35 & 0.33 & 0.36 & 0.38 & 0.08 & 0.84 & 0.83 & 0.7 & 0.74 & 0.64 \\
\hline Tot-Cl & $\%$ & 0.11 & 0.75 & 0 & 0.06 & 0 & 0 & 0.01 & 0.24 & 0.29 & 0.22 & 0.27 & 0.17 \\
\hline Tot-Na & $\%$ & 0.61 & & 0 & 0 & 0 & 0 & 0 & & & & & \\
\hline Tot-Pt & $\%$ & 1.93 & 2.57 & 2.73 & 2.64 & 2.4 & 3.26 & 0.14 & 2.86 & 3.11 & 2.50 & 3.12 & 2.23 \\
\hline Tot-As & $\%$ & & & 0 & 0 & 0 & 0 & 0 & 0.06 & 0.06 & 0 & 0.03 & 0 \\
\hline Tot-Sn & $\%$ & & & 0 & 0.19 & 0.17 & 0 & 0.07 & 0.18 & 0.06 & 0.03 & 0.01 & 0.05 \\
\hline Tot-Pb & $\%$ & & & 0 & 0.16 & 0 & 0 & 0 & 0.05 & 0 & 0.04 & 0.03 & 0 \\
\hline Tot-Cd & $\%$ & 0.1 & & 0.02 & 0 & 0.04 & 0.07 & 0 & 0.01 & 0.04 & 0.03 & 0.03 & 0.05 \\
\hline Tot-Ti & $\%$ & 0.31 & 0.03 & 0.39 & 0.69 & 0.18 & 0.29 & 0.15 & 0.01 & 0.03 & 0.03 & 0.01 & 0.04 \\
\hline
\end{tabular}

The application of compost increased the available-P roughly by a factor of five, although this is still classified as low, whereas the application of the SROP fertilizer increased the available-P 200 times to $80 \mathrm{ppm}$, which is classified as very high. The phosphor content of the SROP fertilizer is higher than that of compost, in which phosphate is abundantly dissolved at a $\mathrm{pH}$ range of 5.5 to 7 [14]. The application of compost increased the available K from $0.07 \mathrm{me} / 100 \mathrm{~g}$ to $0.24 \mathrm{me} / 100 \mathrm{~g}$ and $1.52 \mathrm{me} / 100 \mathrm{~g}$, respectively, whereas the application of the SROP fertilizer further increased the available $\mathrm{K}$ to very high concentrations (26.27 me/100 g and $80.09 \mathrm{me} / 100 \mathrm{~g}$, respectively). The increase in the available $\mathrm{K}$ in the tin-tailing soil media might be due to the fact that the compost contained $0.56 \% \mathrm{~K}$ and the SROP fertilizer contained $2.76 \% \mathrm{~K}$ and that there was a significant increase in the CEC value. 
The application of SROP fertilizer more significantly increased the $\mathrm{Ca}$ and $\mathrm{Mg}$ contents of the tintailing soil than did the compost. The $\mathrm{Ca}$ and $\mathrm{Mg}$ contents of the tin -tailing soil increased with increases in the dose of each of the soil-improving organic matters. This is because the $\mathrm{Ca}$ and $\mathrm{Mg}$ contents of the SROP fertilizer were higher than those of the compost. Additionally, the $\mathrm{pH}$ became neutral and when the CEC increased, this caused an increase in the Ca and Mg contents [14].

The application of compost increased the available-P roughly by a factor of five, although this is still classified as low, whereas the application of the SROP fertilizer increased the available- P 200 times to $80 \mathrm{ppm}$, which is classified as very high. The phosphor content of the SROP fertilizer is higher than that of compost, in which phosphate is abundantly dissolved at a pH range of 5.5 to 7 [14]. The application of compost increased the available $\mathrm{K}$ from $0.07 \mathrm{me} / 100 \mathrm{~g}$ to $0.24 \mathrm{me} / 100 \mathrm{~g}$ and $1.52 \mathrm{me} / 100 \mathrm{~g}$, respectively, whereas the application of the SROP fertilizer further increased the available $\mathrm{K}$ to very high concentrations (26.27 me/100 g and $80.09 \mathrm{me} / 100 \mathrm{~g}$, respectively). The increase in the available $\mathrm{K}$ in the tin-tailing soil media might be due to the fact that the compost contained $0.56 \% \mathrm{~K}$ and the SROP fertilizer contained $2.76 \% \mathrm{~K}$ and that there was a significant increase in the CEC value.

The application of SROP fertilizer more significantly increased the $\mathrm{Ca}$ and $\mathrm{Mg}$ contents of the tintailing soil than did the compost. The $\mathrm{Ca}$ and $\mathrm{Mg}$ contents of the tin -tailing soil increased with increases in the dose of each of the soil-improving organic matters. This is because the $\mathrm{Ca}$ and $\mathrm{Mg}$ contents of the SROP fertilizer were higher than those of the compost. Additionally, the $\mathrm{pH}$ became neutral and when the CEC increased, this caused an increase in the $\mathrm{Ca}$ and $\mathrm{Mg}$ contents [14].

Actually, some metal elements in the tin tailing, such as $\mathrm{Al}, \mathrm{Mn}$, and Fe, were in the normal range and not toxic to the environment or plant life (Table 1). The application of compost and SROP fertilizer served to maintain their low toxicity. We observed almost no Mo content in pure tin-tailing soil, but the Mo content increased with the application of the soil-improving organic matter. The high toxicity of the elements of $\mathrm{B}, \mathrm{Cu}, \mathrm{Zn}$, and $\mathrm{Cd}$ in the tin-tailing soil can be drastically decreased with the application of soil-improving organic matter so that they are not so environmentally toxic, although they were still not completely safe (Table 1 ). The element $\mathrm{Cd}$ was even removed. The increase in $\mathrm{pH}$ was the main causal factor in the decreased toxicity and mobility of the metals in the tailing [14, 15].

The application of soil-improving organic matter has a significant impact on the mean increases in height, diameter, and final dry weight of the Kemiri Sunan tree growth in the 12 -weeks study period. The application of SROP tended to be more effective than that of compost. However, a 5-10\% increase in the dose had a relatively significant impact. The application of a small quantity of soil-improving organic matter yielded a significant impact on the tin-tailing soil. It was a effective in improving the fertility of the soil and the growth of plants. Very intensive maintenance by a monthly application of urea, SP-36, and $\mathrm{KCl}$ fertilizers and frequent watering [16] has also been shown to improve plant growth. The balanced application of soil-improving organic materials and fertilizers is considered to synergistically improve the environmental quality and growth of plants in rehabilitation programs for post-tin-mining land.

The growth of the Kemiri Sunan tree could improve marginal land areas and have a high economic benefit in the production of firewood and animal fodder [16]. The increase in $\mathrm{pH}, \mathrm{CEC}$, and soil fertility is correlated with the increase in the growth of the Kemiri Sunan tree, but this impact is determined, not by any single factor, but by the interaction of various environmental and genetic factors. After all treatments, we found the $\mathrm{N}$ content of the tissue of the Kemiri Sunan tree to be much higher than the $1.5 \%$ required by the plant, because it is legume plant that can fix atmospheric $\mathrm{N}_{2}$. However, the application of compost and SROP had no significant impact on the $\mathrm{N}$ content in the tissue, which indicates the absorption and fixation of atmospheric $\mathrm{N}_{2}$.

The application of compost and SROP can increase the P content in tissue in accordance with the increase in the available $\mathrm{P}$ in soil. An increase in $\mathrm{P}$ is very important because it plays an important role in energy transfer, photosynthesis, glucose and starch transformation, nutrition distribution in the plant, and genetic marker transfers to the next generation [14]. Although we found the available $\mathrm{K}$ in the tintailing media to have increased, the $\mathrm{K}$ content in the plant tissue remained essentially the same because 
it was relatively easy for the $\mathrm{K}$ to leach, regardless of its significant contribution to the plant in facing various stress conditions. We found the absorption of the elements $\mathrm{Ca}, \mathrm{Mg}$ and $\mathrm{S}$ by the plant to generally increase to the normal limit after the application of soil-improving organic matters (Table 1) [14].

The absence of interference of the element $\mathrm{Al}$ in the growth of the Kemiri Sunan may be due to the large quantity of $\mathrm{Al}$ bound with the ligands (ions or molecules surrounding it), or else it was in nontoxic form for plants, such as alumino-silicates and precipitates [14]. The presence of Ti can stimulate plant growth by stimulating the chlorophylls content, enzymatic activities, and absorption of micro- and macro nutrients [17]. We found the absorption of Ti to have occurred without any interference with its growth, thus becoming one of the potential solutions to environmental pollution by the element $\mathrm{Ti}$.

The Cd absorbed by the Kemiri Sunan tree generally accumulated in its roots rather than its leaves. This indicates that the plant tolerates the toxicity of dangerous heavy metals by preventing their translocation from its roots to above -ground tissues. Although it was not a phyto-extraction agent, the tree might be considered as a phyto-stabilization agent because the accumulation of $\mathrm{Cd}$ in its roots can stabilize the condition of $\mathrm{Cd}$ by reducing its mobility and decreasing the possibility of food chain contamination [13].

\section{Conclusions}

Soil from tropical post-tin-mined acid soil ( $\mathrm{pH}$ 5.34) dominated by sand particles (88\%) with a very low cation exchange capacity, very low nutrient content (available and total- $\mathrm{N}, \mathrm{P}, \mathrm{K}, \mathrm{Ca}, \mathrm{Mg}$ ), and high toxicities of $\mathrm{Zn}, \mathrm{Cu}, \mathrm{B}, \mathrm{Cd}$ and $\mathrm{Ti}$, still have low toxicities of $\mathrm{B}, \mathrm{Zn}, \mathrm{Cu}, \mathrm{Ti}, \mathrm{Cd}$. Soil amendments of organic paramagnetic humus and compost can improve soil quality by increasing the $\mathrm{pH}$, available- $\mathrm{P}$, and $\mathrm{K}$, and cation exchange capacity while also maintaining their low toxicity. Growth (as measured by height, diameter, biomass, top-root ratio) of the exotic pioneer plant Reutealis trisperma increases soil quality following the application of proper soil amendments.

\section{Acknowledgments}

The authors are grateful for the financial support provided by The Ministry of Research, Technology and Higher Education RI, Centre of Agro-technology Innovation (PIAT UGM) and Universitas Gadjah Mada Yogyakarta Indonesia. We gratefully acknowledge the funding from USAID through the SHERA program- Centre for Development of Sustainable Region (CDSR). The authors also gratefully acknowledge PT Timah, BPDASHL Baturusa Cerucuk and Pemda Bangka for providing field facilities.

\section{References}

[1] Agus C, Karyanto O, Hardiwinoto S, Haibara K, Kita S, Toda H. Legume cover crop as a soil amendment in short rotation plantation of tropical forest. J. For. Env, 2003; 45(1): 13-19.

[2] Agus C, Karyanto O, Kita S, Haibara K., Toda H, Hardiwinoto S, Supriyo H, Na'iem M, Wardana W, Sipayung M, Khomsatun, Wijoyo S. Sustainable site productivity and nutrient management in a short rotation Gmelina arborea plantation in East Kalimantan. Indonesia New Forest J. 2004; 28: 277-285.

[3] Agus C, Sunarminto BH, Suhartanto B, Pertiwiningrum A, Setiawan I. Wiratni, Pudjowadi D. Integrated Bio-cycles Farming Ssystem for production of Bio-gas through. Gama Digester, Gama Purification And Gama Compressing Journal of Japan Institute of Energy. 2011; 90(11) : 1086-90.

[4] Agus C, Wulandari D. The abundance of pioneer vegetation and their interaction with endomycorrhiza at different land qualities after merapi eruption. 2012; Jurnal Manajemen Hutan Tropika 18(3): 145-154.

[5] Agus C, Pradipa E, Wulandari D, Supriyo H, Saridi, Dan HD. Peran Revegetasi Terhadap Restorasi Tanah pada Lahan Rehabilitasi Tambang Batubara di Daerah Tropika. Jurnal Manusia dan Lingkungan. 2014; 21(1):60-66.

[6] Agus C, Putra PB, Faridah E., Wulandari D, Napitupulu RNP. Organic carbon stock and their dynamics in rehabilitation ecosystem areas of post open coal mining at tropical region. Procedia Engineering, 2016; 159: 329-337.

[7] Agus C, Wulandari D, Primananda E, Hendryan A, Harianja V. The role of soil amendment on tropical post tin mining area in bangka island indonesia for dignified and sustainable environment and life. IOP Conf. Ser.: Earth Environ. Sci, $2017 ; 83$ 
012030

[8] Cahyanti PAB, Agus C. Development of landscape architecture through geo-eco-tourism in tropical karst area to avoid extractive cement industry for dignified and sustainable environment and life. IOP Conf. Ser.: Earth Environ. Sci. 2017; 83 012028

[9] Agus C. Development of Blue Revolution Through Integrated Bio-cycles System on Tropical Natural Resources Management. In: Leal Filho W., Pociovălișteanu D., Borges de Brito P., Borges de Lima I. (eds) Towards a Sustainable Bioeconomy: Principles, Challenges and Perspectives. World Sustainability Series. Springer, Cham. 2018; 155-172.

[10] Forest Watch Indonesia. 2014. Potret Keadaan Hutan Indonesia Periode 2009-2013. Forest Watch Indonesia. Bogor, Indonesia.

[11] Kuncaka A. Slow Release Organic Paramagnetic (SROP) Fertilizer sebagai Model Humus Sintetis Untuk Mengantarkan Terwujudnya Industri Pertanian Raksasa Nasional yang Berkelanjutan, Pidato Dies Natalis ke-58 Fakultas MIPA UGM. 19 Desember 2013. Yogyakarta

[12] Krstic D, Djalovic I, Nikezic D, Bjelic D. Aluminium in acid soils: Chemistry, toxicity and impact on maize plants. Food Production-Approaches, Challenges and Tasks. 2012; 13: 231-242.

[13] Ashraf MA., Maah MJ, Yusoff I. Heavy metal accumulation in plants growing in ex tin mining catchment. International J. of Env. Sci. and Tech.: (IJEST), 2011; 8(2): 401-416.

[14] Foth HD. Fundamental of Soil Sciences. 8th ed. John Wiley and Sons, Inc. USA, 1990.

[15] Moraghan JT, Mascagni HJ. Environmental and soil factors affecting micronutrient deficiencies and toxicities. In: J. J. Mortvedt (ed), Micronutrients in Agriculture, SSSA Book Ser. 4. SSSA, Madison, WI. 1991;371-425.

[16] Audina MN, Maxiselly Y, Dan SR. Pengaruh Kerapatan Naungandan Frekuensi Penyiraman Terhadap Pertumbuhan Bibit Kemiri Sunan (Reutealis trisperma (Blanco) Airy Shaw). Jurnal Kultivasi. Sumedang.

[17] Carvajal, M. Dan C.F. Alvaraz. Why Titanium is A Beneficial Element for Plants. Journal of Plant Nutrition. 1998; 21. Taylor and Francis. 